\title{
Editorial
}

\section{Neuropediatrics and the 40th Annual Meeting of the Society for Neuropediatrics}

\author{
Martin Staudt ${ }^{1,2}$ \\ ${ }^{1}$ Clinic for Neuropediatrics and Neurorehabilitation, Epilepsy Center \\ for Children and Adolescents, Schön Klinik, Vogtareuth, Germany \\ ${ }^{2}$ Department of Pediatric Neurology and Developmental Medicine, \\ University Children's Hospital, Tübingen, Germany
}

Neuropediatrics 2014;45:205.

\section{To the Readers of Neuropediatrics}

In September 2014, we cordially invite you to celebrate with us the 40th Annual Meeting of the Society for Neuropediatrics (Gesellschaft für Neuropädiatrie). This meeting will, now for the fourth time, take place as part of the "Neurowoche," which merges the meetings of the German neuromedical societies (Deutsche Gesellschaft für Neurologie, Deutsche Gesellschaft für Neuroradiologie, Deutsche Gesellschaft für Neurochirurgie, and Deutsche Gesellschaft für Neuropathologie und Neuroanatomie) to one joint conference. This conference (www.neurowoche2014.org) will take place on September 15-19, 2014, in Messe München in Munich (thereby preceding the famous Oktoberfest, which opens on September 20, 2014), and we expect up to 7,000 participants from all fields of neuromedicine.

This joint meeting offers unique chances for live discussions on important neurological issues, with enrollment of specialists from all disciplines. These discussions will take place in "interdisciplinary sessions," and will cover the following topics: "disorders of the spinal cord," "neurological intensive care," "movement disorders," "vascular disorders," "inflammatory disorders," and "epilepsy"-all with contributions also from pediatric neurology.

A special highlight of the 40th Annual Meeting of the Gesellschaft für Neuropädiatrie will be the Peter-EmilBecker-Price Award lecture, to be held by Dr. Pasko Rakic, Yale University, on "Dislocation Syndrome: Disorders of
Neuronal Migration." The award is presented to honor Dr. Rakic's ground-breaking discoveries on the development of the cortex, which form the basis for today's understanding of many neuropediatric disorders, especially of cortical malformations. We are also looking forward to the lecture of this year's awardee of the DESITIN Jungforscherpreis, Dr. Florian Brackmann, on "Activin A Regulation under Hypoxia in the Neonatal Mouse Brain.”

The Gesellschaft für Neuropädiatrie could accept 70 free submissions for platform presentations and almost 100 submissions for poster presentations. The abstracts of these free contributions will be published in an abstract supplement of Neuropediatrics, but in contrast to previous meetings, not in print but only online. This supplement will be available at the official Neuropediatrics Web site on ThiemeConnect. The link to this Web site will also be established on the homepage of the Gesellschaft für Neuropädiatrie, www.neuropaediatrie.com.

We are looking forward to welcoming you in Munich!

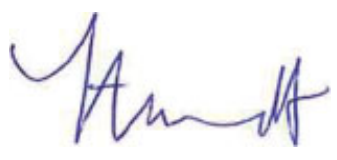

Congress President Gesellschaft für Neuropädiatrie
Address for correspondence Prof. Martin Staudt, MD, Clinic for Neuropediatrics and Neurorehabilitation, Epilepsy Center for Children and Adolescents, Schön Klinik Krankenhausstrasse 20, D-83569

Vogtareuth, Germany (e-mail: mstaudt@schoenkliniken.de). (c) 2014 Georg Thieme Verlag KG Stuttgart · New York
DOI http://dx.doi.org/ 10.1055/s-0034-1386615. ISSN 0174-304X. 